\title{
Stand out of my Sunlight: The Mediating Role of Climate Change Conspiracy Beliefs in the Relationship between National Collective Narcissism and Acceptance of Climate Science
}

Paul Bertin ${ }^{1}$, Kenzo Nera ${ }^{2,3}$, Katarzyna Hamer ${ }^{4}$, Isabella Uhl-Haedicke ${ }^{5}$ and Sylvain Delouvée 6

1. Université Côte d'Azur, LAPCOS, France

2. Center for Social and Cultural Psychology, Université Libre de Bruxelles, Bruxelles, Belgium

3. Fonds de la Recherche Scientifique, Bruxelles, Belgium

4. Institute of Psychology, Polish Academy of Sciences, Warsaw, Poland

5. Environmental Psychology, University of Salzburg, Salzburg, Austria

6. Univ Rennes, LP3C (Laboratoire de Psychologie : Cognition, Comportement, Communication), Rennes, France

\section{Author Note}

Correspondence concerning this article should be addressed to Paul Bertin, Laboratoire d'Anthropologie et de Psychologie Cliniques, Cognitives et Sociales, Campus Saint Jean d'Angely / SJA3 / MSHS Sud-Est, 24 avenue des diables bleus, 06357, Nice Cedex 4, Université Côte d'Azur, Nice, France. Email: pbertin@ unice.fr 


\section{COLLECTIVE NARCISSISM AND CLIMATE CHANGE CONSPIRACY BELIEFS}

Acknowledgments: We are thankful to Jennifer Bastart, Romain Raymondie and Dirk Steiner for their help in the translation of the scales, and to Kathleen McColl for her useful comments on the manuscript.

Funding: This project was supported by l'Agence Nationale de la Recherche (ANR) for the Project CONSPIRACY (ANR-17-CE39-0010-01).

Manuscript accepted for publication at Group Processes and Intergroup Relations 


\title{
COLLECTIVE NARCISSISM AND CLIMATE CHANGE CONSPIRACY BELIEFS
}

\begin{abstract}
Despite the scientific consensus about the anthropogenic nature of climate change, there are still obstacles hindering society from acknowledging the severity of the situation. Notably, previous research suggests that climate change threats can cause people to display ethnocentric reaction to preserve the ingroup's interests. In this research, we investigate the relation between collective narcissism and attitudes towards climate science. We argue that national collective narcissism is negatively associated with the acceptance of climate science. We further hypothesized that this relation might be mediated by conspiracy beliefs about climate change, because narcissistic identifiers are prone to hold conspiracy beliefs. In a pilot Study $(N=409)$, we found that national collective narcissism was significantly associated with climate change conspiracy beliefs. In Study $1(N=295)$, climate change conspiracy beliefs mediated the negative relation between national collective narcissism and acceptance of climate science. In Study $2(N=375)$, this mediation was replicated when controlling for other forms of climate skepticism. Lastly, general conspiracy mentality did not mediate this relation, which emphasizes the importance of considering the specificity of climate change conspiracy theories (rather than generic propensity to believe in conspiracy theories) in understanding distrust toward climate science.
\end{abstract}

Keywords: conspiracy theories, collective narcissism, climate change, science acceptance, climate skepticism, conspiracy mentality, attitudes towards climate science Word count: 6777 
Stand out of my Sunlight: The Mediating Role of Climate Change Conspiracy Beliefs in the Relationship between National Collective Narcissism and Acceptance of

\section{Climate Science}

Climate change is arguably one of the biggest threats of our times. After decades of debate, there is now a scientific consensus about the fact that climate change is due to human activities (Cook et al., 2013, 2016). However, the scientific consensus is one thing, its acceptance by the population is another. Appraising the factors driving the acceptance and rejection of climate science is crucial to motivate mitigation behaviors aimed at reducing the consequences of climate alteration (Van der Linden et al., 2015). As it turns out, acceptance of climate science by the public remains low and is even decreasing in many countries (Tranter \& Booth, 2015). Thus, research aiming at understanding such distrust is more vital than ever (Cologna \& Siegrist, 2020).

A large body of literature has investigated the mechanisms involved in the acceptance and rejection of climate science from an individualistic approach (Bamberg, 2013), but we still lack knowledge about this phenomenon from a collective approach. Such an approach was adopted by the Social Identity Model of Pro-Environmental Action (SIMPEA; Fritsche et al., 2017). This model predicts that skepticism toward climate change might come from ethnocentric ingroup identification and group-based cognition as reactions to climate threat. In line with SIMPEA's prediction, recent findings shows that national collective narcissism, a defensive form of national attachment (Golec de Zavala et al., 2009; Cichocka, 2016), is related to support for anti-conservation policies, potentially as a way to protect national sovereignty (Cislak et al., 2018).

However, the magnitude of national narcissistic identifiers' opposition to environmentalism is unclear: Is this defensive national attachment solely related to antienvironmentalism at the national level, or does it reflect a more general rejection of 


\section{COLLECTIVE NARCISSISM AND CLIMATE CHANGE CONSPIRACY BELIEFS}

environmental concerns at a global level, and climate science in particular? We argue for the latter, with the rationale that climate science's recommendations for global policies and international conventions might threaten the propensity of national narcissistic identifiers to perceive their national group as sovereign. Moreover, due to their defensive-based identification, collective narcissistic identifiers are prone to reframe perceived threats into plots occurring against the ingroup, and hence to hold conspiracy beliefs (Cichocka, 2016). Thus, we argue that climate change conspiracy beliefs might explain the relation between national collective narcissism and the rejection of climate science. Three studies were conducted to test these hypotheses.

\section{The group-level understanding of climate science denial}

The rejection of scientific consensus, also called denialism (Diethelm \& McKee, 2009), and operationalized in this paper as (climate) science rejection, has been rising during the past decade, notably through anti-science movements about various scientific topics such as vaccines, tobacco disease, evolution, and so on (Hotez, 2020a, 2020b). Research has shown that some forms of denialism are interrelated (Hansson, 2017). For example, denialism about vaccination is positively associated with denialism about GMOs (Rutjens et al., 2018), and denialism about evolution is positively associated with denialism about climate change (Ecklund et al., 2017). However, it is also important to acknowledge that each form of denialism seem to gather distinct communities (Bliuc et al., 2015; Lewandowsky \& Oberauer, 2016; Washburn \& Skitka, 2017). These particularities call for specific investigations of collectives and groups processes involved in the rejection of a given scientific theory.

As it pertains to a global threat, climate denialism also ought to be studied at the group-level. Indeed, it has been shown that the anxiety triggered by global threats, such as climate change, increases self-categorization at a collective level (Fritsche et al., 2011; Jonas et al., 2014). However, in such situations, the level of inclusivity of the salient social identity 


\section{COLLECTIVE NARCISSISM AND CLIMATE CHANGE CONSPIRACY BELIEFS}

is not systematically congruent with the level of inclusivity of the global threat (i.e., global identification or identification with all humanity, McFarland et al., 2019). Rather, when confronted with global threats, self-categorization often occurs at a national and ethnocentric level (Uhl et al., 2018). For example, it has been shown that when facing climate threat, high national British identifiers displayed defensive group-based reactions through increased system justification (Fritsche et al., 2012, Study 2). Relatedly, Bliuc et al. (2015) found a higher level of national identification among climate skeptics than among "believers," who, in turn, reported a higher level of identification with all humanity.

Explanations have been proposed to explain ethnocentric responses to global threats: That such self-categorization might serve a function of defense of the societal status quo (Feygina, 2012), or that it enables ingroup protection over climate threat consequences (Fritsche et al., 2011). Others argued that this reaction has a coping function and aims at reducing climate change-related anxiety (Haltinner \& Sarathchandra, 2018; Uhl et al., 2016, 2018). Notably, Uhl et al. (2018) found ingroup affirmation fostered an ethnocentric national response to climate threat, which in turn was linked to a decrease in pro-environmental behavioural intentions.

To sum up, when facing climate threats, some individuals tend to react by selfcategorizing themselves at the level of the national group. Such ethnocentric reactions are related to detrimental environmental consequences. Thus, an ethnocentric reaction to climate threat might constitute a group-level predictor of the rejection of climate science.

\section{Collective narcissism and the rejection of climate science}

According to Cichocka (2016), there are two kinds of ingroup attachment: Secure attachment, which is related to virtuous outcomes at the group-level, and defensive attachment which is associated with high sensitivity to threat and negative group-level 


\section{COLLECTIVE NARCISSISM AND CLIMATE CHANGE CONSPIRACY BELIEFS}

consequences. As it seems to be heightened by feelings of being threatened, we could hypothesize that previously discussed findings regarding the detrimental consequences of ethnocentric reactions to climate threat are related to the defensive part of national attachment.

This defensive group attachment has been previously operationalized through the notion of collective narcissism (Golec de Zavala et al., 2009, 2013; Hamer et al., 2018). Collective narcissism is "an attitudinal orientation towards one's in-group that captures a grandiose and inflated image of the in-group that is contingent upon external recognition of one's group's worth" (Cichocka, 2016, p. 287). Collective narcissism can be applied to virtually any type of groups, from football fans (Larkin \& Fink, 2019) to religious groups (Marchlewska et al., 2019). However, examining collective narcissism at the level of the national group is particularly relevant when investigating environmental issues. Indeed, environmental policies are often decided at the national level, and national identification is salient in the context of international relations and supranational recommendations (e.g., Intergovernmental Panel on Climate Change (IPCC) reports are addressed to nation-states).

Collective narcissism is related to, but distinct from, individual narcissism (for a review, see Golec de Zavala et al., 2019). The latter was already found to be a negative predictor of concern for the environment. Indeed, past research has shown that individual narcissism significantly and negatively predicted public action on climate change (Van der Linden \& Rosenthal, 2016), environmental ethics (Bergman et al., 2013), connectedness to nature (Frantz et al., 2005, study 2) and valuation of green behaviors (Naderi \& Strutton, 2014, Study 1).

By contrast, as far as we know, only one published paper investigated the relationship between collective narcissism and environmental issues. Cislak et al. (2018) showed that in Poland, high narcissistic national identifiers supported anti-conservation policies about the 


\section{COLLECTIVE NARCISSISM AND CLIMATE CHANGE CONSPIRACY BELIEFS}

Bialowieza forest, even though it is part of the national environmental heritage. The authors found that this connection was partly mediated by the support for decisional independence toward the European Union concerning environmental policies. The authors proposed that narcissistic identifiers might have an instrumental view of their own natural environment, and that they might care for it as long as it enables the group's sovereignty to be consolidated.

In this research, we sought to investigate further the negative relationship between national collective narcissism and environmental concerns, extending this question to climate science acceptance. By advocating for the power and sovereignty of their ingroup, narcissistic identifiers might not only be opposed to anti-conservation policies at the national level, but also to climate science at the international level.

Previous findings support the hypothesis that narcissistic identifiers reject supranational influences. Narcissistic identification has been related to the valuation of national independence (Golec de Zavala et al., 2019). Moreover, Marchlewska et al. (2018) argued that collective narcissism is closely related to populism in perceiving one's ingroup as great, yet unfairly deprived. This sense of unfair deprivation predicted voting for the populist party in Poland, supporting Brexit in the UK, and voting for Trump in the US. Finally, collective narcissists are hypersensitive to ingroup criticism, perceiving an ambiguous message as insulting (Golec de Zavala et al., 2016). Together, this evidence indicates that climate science might be perceived as constraining one's narcissistic group, consequently leading to rejection of the scientific consensus.

Last, it has also been proposed that collective narcissistic identifiers are more likely to express hostility toward issues challenging the social order and traditional habits (for a review, see Golec de Zavala \& Lantos, 2020). In Poland, religious collective narcissism has been related to the belief that people advocating gender equality are conspiring to harm the traditional values and structure of the country (Marchlewska et al., 2019). A similar form of 


\section{COLLECTIVE NARCISSISM AND CLIMATE CHANGE CONSPIRACY BELIEFS}

hostility might arise in the face of climate issues, due to the everyday recommendations intended to lower individuals' carbon footprint (e.g. decreasing meat consumption, StollKleemann \& Schmidt, 2017). This hostility could be associated with conspiracy framing of perceived threat to the group's values and power, as observed by Marchlewska et al. (2019) in the case of catholic collective narcissism in Poland. Indeed, conspiracy beliefs are a core feature of collective narcissism (Cichocka et al., 2015), as well as of science denialism (Diethelm \& McKee, 2009), and could play a major explicative role in their relationship.

\section{The mediating role of conspiracy beliefs}

Conspiracy beliefs can be defined as "attempts to explain the ultimate causes of significant social and political events and circumstances with claims of secret plots by two or more powerful actors" (Douglas et al., 2019, p. 4). Conspiracy beliefs are related to numerous detrimental consequences in various domains such as health (Bertin et al., 2020; Jolley \& Douglas, 2014b; Marinthe et al., 2020), distrust toward political institutions (Einstein \& Glick, 2013), intergroup prejudice (Jolley et al., 2019) and justification of violence (Jolley \& Paterson, 2020).

In the context of climate change and pro-environmental action, conspiracy theories are negatively related to intentions to reduce one's carbon footprint (Jolley \& Douglas, 2014) and pro-environmental behavior (Van der Linden, 2015). Douglas and Sutton (2015) described the specificities of climate change conspiracy beliefs, whose content "postulates that global warming is not happening and instead that scientific findings are being exaggerated or fabricated by people who have something to gain" (p. 100). Climate change conspiracy theories grew over the disputed debate about climate change existence (Goertzel, 2010), and are a core feature of climate change denialism (Diethelm \& McKnee, 2009; Goldsby \& Kollage, 2015). 


\section{COLLECTIVE NARCISSISM AND CLIMATE CHANGE CONSPIRACY BELIEFS}

The relationship between narcissistic identification and conspiracy beliefs has been documented in a diversity of contexts, and for a variety of conspiracy beliefs. For example, national collective narcissism was shown to be associated with belief in a global conspiracy driving the 2016 American elections (Golec de Zavala \& Federico, 2018), as well as with belief in COVID-19 conspiracy beliefs among British and American participants (Sternisko et al., 2020). In Poland, catholic collective narcissism was associated with conspiracy beliefs pertaining to gender movements (Marchlewska et al., 2019). Yet, as far as we know, this relation has never been documented empirically for climate change conspiracy beliefs.

Because of the documented relations between collective narcissism and conspiracy beliefs on the one hand, and climate change conspiracy and climate change denialism on the other, we hypothesize that conspiracy beliefs might play a mediating role in explaining the relationship between collective narcissism and the rejection of climate science. It is worth noting that previous research on the relationship between concern for global warming and conspiracy beliefs mainly focused on conspiracy mentality (for a review, see Uscinski et al., 2017). Thus, it appears that specific climate change conspiracy beliefs have been underinvestigated in the study of the rejection of climate science. In this research, following the suggestion of Sternisko et al. (2020), we focus on climate change conspiracy beliefs, rather than conspiracy mentality. According to these authors, conspiracy beliefs can assume a different function, depending on the context in which they are endorsed. Their approach suggests that specific conspiracy theories might be more relevant than general conspiracy mentality (i.e. the general propensity to endorse conspiracy beliefs) to understand processes rooted in social identity dynamics.

\section{The Current Studies}

We conducted three studies on French samples to test the mediation model introduced above. In a pilot study $(N=409)$ we checked the connection between national collective 


\section{COLLECTIVE NARCISSISM AND CLIMATE CHANGE CONSPIRACY BELIEFS}

narcissism and climate change conspiracy beliefs. In Study $1(N=295)$, we tested how this relationship predicted rejection of climate science. In Study $2(N=375)$, we re-tested these connections when controlling for other forms of climate skepticism. We also tested conspiracy mentality (i.e. the general propensity to endorse conspiracy beliefs; see Bruder et al., 2013) as an alternative mediator in the relationship between collective narcissism and the rejection of climate science in order to further explore the context-dependency of narcissist identifiers' appeal to conspiracy beliefs.

For all three studies, materials, data, and analyses are openly available on the Open Science Framework: https://osf.io/cnmey/?view_only=1e75c061d7434458864d6ace1ad72ed5.

Analyses were run using Jamovi (The jamovi project, 2020). Internal consistency was estimated using McDonald's omega which is a more accurate coefficient than Cronbach's alpha (Dunn et al., 2014). The sample sizes of the three studies were all above the threshold of $N=250$ required for stabilized correlations (Schönbrodt \& Perugini, 2013).

In all studies, we systematically controlled for non-narcissistic national identification, age and gender when conducting the analyses. National identification is usually highly correlated with national collective narcissism (Cichocka et al., 2016). By controlling for this overlapping variable, we sought to isolate the narcissistic component of national attachment. Age and gender are not systematically related to conspiracy beliefs, however, a recent poll in France revealed that younger people are more prone to endorsing conspiracy theories (Conspiracy watch, 2019). In a similar vein, Galliford and Furnham (2017) recently found age and gender to be significantly related to conspiracy beliefs. Thus, in order to control for this potential noise (Douglas \& Sutton, 2018), we controlled for gender and age as well.

\section{Pilot Study}




\section{COLLECTIVE NARCISSISM AND CLIMATE CHANGE CONSPIRACY BELIEFS}

Before testing our model, we conducted a pilot study to test the basic assumption underlying our argument, namely, that the relation between collective narcissism and conspiracy beliefs found in previous research (e.g. Cichocka et al., 2016; Douglas et al., 2019) holds for conspiracy beliefs about climate science as well. Therefore, we hypothesize that collective narcissism would predict conspiracy beliefs about climate change $\left(\mathrm{H}_{1}\right)$.

\section{Method}

\section{Participants and procedure}

The survey was conducted online as part of a larger project and disseminated on Facebook, Linkedin \& Twitter among a French audience. Overall, 609 people answered the questionnaire. Four hundred and nine participants (299 women and 3 "other", $M_{\text {age }}=28.4, S D$ $=11.4, \min =18, \max =72$ ) remained after excluding those who did not fully complete the questionnaire $(N=152)$, failed to answer the attention or seriousness checks correctly $(N=$ $44)$, or were under 18 years old $(N=3)$. One participant was removed as he/she explicitly answered for two people. These exclusions did not affect the results (see the supplementary analyses file for the detailed analyses without exclusions). For a given a power of .90 , the sample size enabled us to detect correlations of $r=.16$ with two-tailed tests.

\section{Measures}

Descriptive statistics are displayed in Table 1. Participants answered to all scales using a 5-point Likert scale ranging from Strongly Disagree (coded 1) to Strongly Agree (coded 5).

National collective narcissism $(\omega=\mathbf{. 8 6})$. We used the Collective Narcissism Scale (Golec de Zavala et al., 2009) to measure participants' national (i.e., French) collective narcissism. We translated the scale into French using a translation - back translation process. Due to length constraint, we used the 5-items version of the scale (e.g. "The French nation deserves special treatment", see Appendix A). 


\section{COLLECTIVE NARCISSISM AND CLIMATE CHANGE CONSPIRACY BELIEFS}

Conspiracy beliefs about climate change $(\omega=\mathbf{. 8 3})$. We used 1 item from (Lewandowsky, Oberauer, et al., 2013) combined with 4 original items to measure climate change conspiracy beliefs (e.g. "Some scientists falsify their results, concluding that climate change is due to humans, in order to gain power and influence", see Appendix B).

National identification $(\omega=\mathbf{. 7 0})$. In order to grasp participants' national identification, we used the related items from the Identification With All Humanity scale (IWAH; McFarland et al., 2012). This scale measures three levels of social identification, namely, the community, national, and humanity levels (e.g. "How close do you feel to each of the following groups?"). We used a 4-items version of the French translation of the IWAH (see Hamer et al., 2020).

\section{Results and discussion}

The correlation matrix (see Table 1) reveals a significant positive correlation between national collective narcissism and conspiracy beliefs about climate change. Surprisingly, we did not find a significant positive relationship between national identification and the two remaining variables (national collective narcissism and conspiracy beliefs about climate change).

[Insert Table 1 here]

To test our hypothesis, we carried out a linear hierarchical regression to test the relationship between national collective narcissism and climate change conspiracy beliefs. We controlled for gender, age, and national identification at Step 1. National collective narcissism was introduced as an independent variable at Step 2. Congruent with $\mathrm{H}_{1}$, national collective narcissism positively predicted climate change conspiracy beliefs $B=.30,95 \% C I[.21 ; .38], t$ $=7.08, p<.001($ see Table 2$)$. 


\section{COLLECTIVE NARCISSISM AND CLIMATE CHANGE CONSPIRACY BELIEFS}

This result corroborates our assumption that the positive relationship between collective narcissism and conspiracy beliefs observed in previous research (see e.g. Cichocka et al., 2016; Douglas, et al., 2019) holds for conspiracy beliefs about climate change as well. In Studies 1-2, we incorporated this relation into a mediation model, in which the negative relation between collective narcissism and acceptance of climate science is mediated by climate change conspiracy beliefs.

\section{Study 1}

In study 1 , we hypothesize that collective narcissism will negatively predict acceptance of climate science $\left(\mathrm{H}_{1}\right)$. Indeed, we suspect that for collective narcissists, climate change science, which calls for supranational cooperation at the expense of narrow national interests, might be perceived as a threat to the sovereignty of the ingroup. We further hypothesize that this relation will be mediated by conspiracy beliefs about climate change $\left(\mathrm{H}_{2}\right)$.

\section{Method}

\section{Participants and procedure}

The pencil and paper survey was conducted among undergraduate students at two French universities. Overall, 301 participants took part in the survey, of which 295 remained (242 women and 1 "other", $M_{\text {age }}=20.1, S D=3.67$, in $=18$, ax $=61$ ) after excluding 5 participants under 18 years old (which is the legal age in France for participating in scientific studies), and 1 participant who was not a French native speaker. These exclusions did not affect the results (see the supplementary analyses file for detailed analyses without exclusions). For a given a power of .90 , the sample size enabled us to detect correlations of $r$ $=.19$ with two-tailed tests.

\section{Measures}




\section{COLLECTIVE NARCISSISM AND CLIMATE CHANGE CONSPIRACY BELIEFS}

Participants responded to all scales using a 5-point scale ranging from 1 (totally disagree) to 5 (totally agree). Means, standard deviations, and inter-scales correlations are displayed in Table 3.

National collective narcissism $(\omega=\mathbf{. 8 2})$. We used a short 5 -items version of the French translation of the collective narcissism scale (Golec de Zavala et al., 2009) assessing narcissistic attachment to the French nation (e.g. "If the French nation had a major say in the world, the world would be a much better place", see Appendix A).

Conspiracy beliefs about climate change $(\omega=.69)$. Due to length restriction, we used three items to determine participants' conspiracy beliefs about climate change (e.g. "In order to increase their profits, some multinationals agree to finance organizations that accuse human beings of being the cause of climate change", see Appendix B).

Acceptance of climate science $(\omega=\mathbf{. 5 8})$. We translated into French four items from Lewandowsky et al. (2013) assessing attitudes toward climate science (e.g., "Human CO2 emissions cause climate change", two reverse-items, see Appendix C).

National identification $(\omega=\mathbf{. 6 7})$. We used the same 4-items scale as in the pilot Study.

[Insert Table 3 here]

\section{Results and discussion}

An inspection of the correlations revealed significant positive relationships between national collective narcissism and conspiracy beliefs about climate change (see Table 3). Both of these variables were negatively related to acceptance of climate science. Contrary to the results from the Pilot study and in accordance with the literature (Cichocka et al., 2016), national collective narcissism was positively related to national identification.

We first tested the main effect of the mediation model, by carrying out a linear regression with collective narcissism as the independent variable and acceptance of climate 


\section{COLLECTIVE NARCISSISM AND CLIMATE CHANGE CONSPIRACY BELIEFS}

science as the dependent variable, controlling for age, gender and national identification (see Table 4). As expected, we found a direct negative effect of collective narcissism on acceptance of climate science, $B=-0.21,95 \% C I[-0.30 ;-0.11], t=-4.48, p<.001$. Hence, congruent with $\mathrm{H}_{1}$, heightened national collective narcissism was associated with lower acceptance of climate science. Notably, national identification was significantly and positively related to acceptance of climate science, $B=0.13,95 \% C I[0.03 ; 0.23], \mathrm{t}=2.54, p=$ .012 .

\section{[Insert Table 4 here]}

We tested the mediation $\left(\mathrm{H}_{2}\right)$ using the "jAMM" (jamovi Advanced Mediation Models) package for jamovi (Gallucci, 2020). Acceptance of climate science was introduced as the dependent variable, collective narcissism as the independent variable, and climate change conspiracy beliefs as a mediator. We controlled for gender, age and national identification for all paths and used bootstrapping with 1000 resamples for bias correction of the indirect effect. Corroborating $\mathrm{H}_{2}$, the main effect was mediated by climate change conspiracy theories, $I E=-0.11(52 \%$ of the total effect), 95\% CI[-0.16; - 0.06], $z=-4.35, p<$ .001 , leaving no significant direct effect, $B=-0.10,95 \% C I[-0.20 ; 0.01], z=-1.87, p=.06^{1}$ (see Figure 1, paths a).

\section{[Insert Figure 1 here]}

Thus, as expected, national collective narcissism is negatively related to acceptance of climate science, and this relation is mediated by climate change conspiracy beliefs.

\section{Study 2}

In Study 2, we wanted to check whether the negative relationship between national collective narcissism and the acceptance of climate science $\left(\mathrm{H}_{1}\right)$ would be mediated by

\footnotetext{
${ }^{1}$ Without controlling for national identification, the pattern of results remains the same $I E=-0.11(57 \%$ of the total effect), 95\% CI[-0.16;-0.06], $z=-4.57, p<.001$, direct effect : $B=-0.07,95 \% C I[-0.17 ; 0.02], z=-1.60, p$ $=.11$.
} 


\section{COLLECTIVE NARCISSISM AND CLIMATE CHANGE CONSPIRACY BELIEFS}

climate change conspiracy beliefs $\left(\mathrm{H}_{2}\right)$, even when controlling for other forms of climate change skepticism. We also tested conspiracy mentality as an alternative mediator $\left(\mathrm{H}_{3}\right)$.

Climate skepticism can be described as "strongly held disbeliefs in or a rejection of the tenets of mainstream climate science" (Poortinga et al., 2011, p. 5). Rahmstorf (2004) differentiates three kinds of climate skepticism, pertaining to different components of the climate change issue: 1) Trend skepticism, denying the reality of climate change in general; 2) Attribution skepticism, denying the anthropogenic origin of climate change and advocating for natural causes; 3) Impact skepticism, not denying the anthropogenic origin of climate change but considering the consequences to be harmless. We hypothesize that these dimensions of skepticism are related to, but different from climate change conspiracy beliefs. Hence, we tested for the uniqueness of climate change conspiracy beliefs in mediating the relation between collective narcissism and attitudes toward climate science by controlling for other kinds of skepticism in the analyses.

Furthermore, whilst the mediating role of climate change conspiracy beliefs in our model could be accounted for by other forms of climate skepticism, it could also be a manifestation of a generic conspiracy mentality (Bruder et al., 2013, Moscovici, 1987), which has been previously linked to rejection of climate science (Lewandowsky et al., 2013) and collective narcissism (Golec de Zavala \& Federico, 2018). Hence, in Study 2, we examined conspiracy mentality as an alternative mediator of the relation between collective narcissism and rejection of climate science.

\section{Method}

\section{Participants and procedure}

The study was disseminated online both among undergraduate students of two French universities and on social media among a French audience (Facebook, Twitter and LinkedIn) in order to add diversity to the sample, compared with the sample for Study 1, which used 


\section{COLLECTIVE NARCISSISM AND CLIMATE CHANGE CONSPIRACY BELIEFS}

participants from two universities only. Overall, 469 participants answered the survey. We excluded 69 participants for not having fully completed the survey, 21 for not being French, 2 for failing the attention check and 2 for being under 18 years old. These exclusions did not affect the results (see the supplementary analyses file for detailed analyses without exclusions). The final sample was made up of 375 participants (264 women and 6 "other", $\left.M_{\text {age }}=25.9, S D=10.1, \min =18, \max =70\right)$, which enabled two-tailed tests correlations of $r$ $=.17$ with a given power of .90 .

\section{Measures}

Unless mentioned, all scales ranged from 1 ("totally disagree") to 5 ("totally agree"). Means, standard deviations, and inter-scales correlations are displayed in Table 4.

National collective narcissism $(\omega=\mathbf{. 8 7})$. We used the full French 9 item version of the collective narcissism scale (Golec de Zavala et al., 2009). Participants answered using a scale ranging from "1-totally disagree" to "6-totally agree" (1 reversed item, see Appendix A).

Conspiracy beliefs about climate change $(\omega=\mathbf{. 8 3})$. As in the Pilot study and Study 1, we used one item from Lewandowsky et al. (2013) together with four new items to assess participants' endorsement of various conspiracy theories about climate change (e.g. "Some companies having invested large sums of money in renewable energies are financing worrisome research about climate change in order to secure their investment", see Appendix B).

Acceptance of climate science $(\omega=\mathbf{. 8 8})$. Because the internal reliability of the scale used in Study 1 was not optimal, we used a different, yet conceptually similar scale for Study 2. We translated into French four items from Lewandowsky et al. (2013) to determine participants' acceptance of climate science (e.g. "I believe that the burning of fossil fuels on the scale observed over the last 50 years has increased", see Appendix C). 


\section{COLLECTIVE NARCISSISM AND CLIMATE CHANGE CONSPIRACY BELIEFS}

National identification $(\omega=\mathbf{. 8 4})$. As in the Pilot study and Study 1 , we computed items about national level of identification from the IWAH scale (McFarland et al., 2012). We used the full 9-item version (e.g. "How much would you say you have in common with the French people", see Hamer et al. (2020) for the French translation).

Climate skepticism. We used four items from Poortinga et al.'s (2011) scale to assess three forms of skepticism about climate change. Trend skepticism was measured using the item "I am uncertain that climate change is really happening", attribution skepticism was measured using the item "Most scientists agree that humans are causing climate change", and impact skepticism was measured using two items (e.g. "It is uncertain what the effects of climate change will be"). In line with Poortinga et al. (2011), participants answered using a scale ranging from "1-totally agree" to "5-totally disagree" (see Appendix D). In the following analysis, trend skepticism and impact skepticism scores were reversed for the ease of interpreting the results, with higher scores reflecting a higher level of skepticism.

Conspiracy mentality $(\omega=\mathbf{8 9})$. We measured the generic propensity to endorse conspiracy beliefs using the French version (Lantian et al., 2016) of the Conspiracy Mentality Questionnaire (CMQ, Bruder et al., 2013). The CMQ is one of the most widely used scales to measure conspiracy mentality (Swami et al., 2017). Participants rated the likelihood of each of the 5 items (e.g. "I think that many very important things happen in the world, which the public is never informed about") on an 11-point scale (from $0 \%=$ 'Certainly not' to $100 \%=$ 'Certain').

\section{Results}

An inspection of the correlations revealed significant positive correlations between national collective narcissism and conspiracy beliefs about climate change, trend skepticism and attribution skepticism (but not impact skepticism), and national identification. There were negative correlations between acceptance of climate science, and national collective 


\section{COLLECTIVE NARCISSISM AND CLIMATE CHANGE CONSPIRACY BELIEFS}

narcissism, as well as with the three types of climate skepticism. All three types of climate skepticism, conspiracy mentality, and conspiracy beliefs about climate change were positively intercorrelated. Last, national identification was significantly and positively related to conspiracy beliefs about climate change and not significantly related to acceptance of climate science (see Table 5).

\section{[Insert Table 5 here]}

We first tested the main effect of the mediation model, by carrying out a linear regression with collective narcissism as the independent variable, and acceptance of climate science as a dependent variable, controlling for age, gender and national identification (see Table 6). We found a direct negative effect of collective narcissism on acceptance of climate science, $B=-0.17,95 \% C I[-0.26 ;-0.08], t=-3.61, p<.001$. As in Study 1 , heightened national collective narcissism was associated with lower acceptance of climate science, validating $\mathrm{H}_{1}$.

\section{[Insert Table 6 here]}

Next, we tested our mediation model to replicate results from Study 1, using the “jAMM” package for jamovi (Gallucci, 2020). We used 1000 bootstraps for bias correction of the indirect effect, with climate change conspiracy beliefs as the mediating variable. For all paths, we controlled for gender, age and national identification. Results showed that climate change conspiracy beliefs mediated the relationship between collective narcissism and acceptance of climate science, $I E=-0.08$ (47\% of the total effect), 95\% CI[-0.12; -.04], $z=-$ $3.85, p<.001$, leaving no significant direct effect $B=-0.09,95 \% C I[-0.19 ; 0.01], z=-1.73, p$ $=.08$ (see Figure 1, paths b) ${ }^{2}$. This is congruent with results from Study 1 and corroborates $\mathrm{H}_{2}$.

\footnotetext{
${ }^{2}$ Without controlling for national identification, the pattern of results remains the same $I E=$ 0.08 (50\% of the total effect), 95\% CI[-0.11; - 0.03], $z=-3.94, p<.001$, direct effect : $B=-$ $0.08,95 \%$ CI[-0.17; 0.02], $z=-1.59, p=.11$.
} 


\section{COLLECTIVE NARCISSISM AND CLIMATE CHANGE CONSPIRACY BELIEFS}

To test $\mathrm{H}_{2}$, we carried out the same mediation analyses, while also controlling for the three other forms of climate skepticism. The indirect effect of climate change conspiracy beliefs remained significant, $I E=-0.037$ (34\% of the total effect), 95\% CI[-0.06; -0.01$], z=-$ $2.47, p=.014$, and national collective narcissism no longer significantly predicted acceptance of climate science, $B=-0.07,95 \% C I[-0.17 ; 0.02], z=-1.61, p=.11$, see Figure 1 (paths c). This corroborates $\mathrm{H}_{2}{ }^{3}$.

Lastly, we examined whether general conspiracy mentality also mediated the relationship between collective narcissism and rejection of climate science. We controlled for age, gender, and national identification. The data did not support a mediation, $I E=0.01$ $(0.01 \%$ of the total effect), $95 \% C I[-0.01 ; 0.01], z=0.59, p=.55$ (see Figure 2). Indeed, conspiracy mentality was not a significant predictor of acceptance of climate science, $B=$ $0.02,95 \% C I[-0.01 ; 0.05], z=1.21, p=.23$, and was not significantly predicted by collective narcissism, $B=0.13,95 \% C I[-0.15 ; 0.40], z=0.90, p=.36$.

[Insert Figure 2 here]

\section{Discussion}

The results of Study 2 replicated results from the Pilot study and Study 1.

Furthermore, climate change conspiracy beliefs still mediated the relation between national collective narcissism and acceptance of climate science when controlling for other types of climate skepticism, in addition to age, gender, and national identification. Thus, our results suggest that climate change conspiracy beliefs play a specific role in the rejection of climate science among collective narcissists.

Furthermore, conspiracy mentality did not mediate the relationship between national collective narcissism and climate science acceptance, in line with the view of Sternisko et al.

\footnotetext{
${ }^{3}$ See the supplementary analyses file for testing of the mediation model using the three forms of climate skepticism as mediators.
} 


\section{COLLECTIVE NARCISSISM AND CLIMATE CHANGE CONSPIRACY BELIEFS}

(2020), according to which social identity motives are likely to lead primarily to contextrelevant conspiracy beliefs. Below, we further discuss further this latter point, as well as our findings, limitations, and prospects for future research.

\section{General discussion}

Across three studies, our mediation model was corroborated. Congruent with our expectations, we found that collective narcissism negatively predicted acceptance of climate science. Furthermore, this relation was mediated by conspiracy beliefs about climate change, even when controlling for different dimensions of climate change skepticism. Furthermore, general conspiracy mentality did not mediate this relationship, which emphasizes the specific role of climate change conspiracy beliefs in the rejection of climate science.

Our results indicate that national collective narcissism is not solely related to specific anti-environmentalism attitudes such as support for anti-conservation policies at the national level (Cislak et al., 2018), but is more deeply and broadly grounded on rejection of climate science. Climate change conspiracy beliefs seem to play a specific role in this relationship. Indeed, such beliefs might reframe climate change threat intro intergroup suspicion and denialism. Following Cislak et al. (2018), we can hypothesize that this suspicious stance against climate science and stakeholders is fed by the motivation to protect the power and sovereignty of one's national ingroup. But this is speculative and more research is needed to test this hypothesis.

The observed mediating role of conspiracy beliefs, but not of conspiracy mentality, is interesting and needs to be further investigated. Based on previous empirical findings, it would not have been surprising to find a positive relation between conspiracy mentality and climate science rejection (Lewandowsky et al, 2013; Van der Linden et al., 2020), and between collective narcissism and conspiracy mentality (Golec de Zavala \& Federico, 2018). One explanation might be that, as far as we know, these studies were conducted in a U.S. 


\section{COLLECTIVE NARCISSISM AND CLIMATE CHANGE CONSPIRACY BELIEFS}

setting. Given its important political and ideological specificities (Van der Linden et al., 2020), research conducted in this context might produce results that cannot be generalized to other countries. This interpretation is supported by recent cross-cultural research, which found the U.S. population to be unique concerning climate skepticism and conspiracy ideology, compared with 24 other countries (Hornsey et al., 2018). But as noted by Van der Linden et al. (2020) and by Golec de Zavala (2020), the recent growth in popularity of right-wing authoritarian governments around the world (Hungary, Poland, Brazil, etc.) may mark the end of this U.S. particularity discussed above. This emphasizes the necessity for future research to replicate this study.

Two frameworks were recently published and intended to explain collective narcissist appeal for conspiracy theories. Based on the meaning maintenance model and on previous research (Golec de Zavala \& Federico, 2018), Golec de Zavala (2020) stated that collective narcissism is impregnated with conspiracy mentality, and is therefore likely to be related to the endorsement of any kind of conspiracy theories. By contrast, Sternisko et al. (2020) advocated that when they respond to social identity motives, people might be only sensitive to some conspiracy theories, depending on their content. As collective narcissism is rooted in social identity motives, collective narcissists might therefore selectively endorse some conspiracy theories that serve such motives. Our findings are in favor of the latter framework, with collective narcissism being related to the rejection of climate science through climate conspiracy beliefs, but not to conspiracy mentality.

However, these two positions are not incompatible, and narcissistic identifiers may have a more pronounced conspiracy mentality than non-narcissistic identifiers, coupled with contextual sensitivity. Indeed, it is tricky to distinguish precisely between dispositional and contextual motives for endorsing conspiracy theories. This point is acknowledged by Sternisko et al. (2020, p.4), who state that "people are driven by multiple motives and 


\section{COLLECTIVE NARCISSISM AND CLIMATE CHANGE CONSPIRACY BELIEFS}

conspiracy theories can meet these various motives at the same time. Further, motives can interact with each other, as can the content and qualities of conspiracy theories". At this point, our results suggest that the speculated conspiratorial mentality component of collective narcissism may not be as quick to endorse a wide variety of conspiracy theories as predicted by Golec de Zavala (2020).

\section{Limitations and future research}

First and foremost, we must acknowledge a limitation lying in the absence of a generic measure of political conservatism in our studies. Indeed, conservative political orientation is a negative predictor of climate science acceptance (Lewandowsky et al., 2013; van der Linden et al., 2020) and also a positive predictor of national collective narcissism (Cichocka, et al., 2016). Regarding climate change acceptance, for example, more than $90 \%$ of books published since 1972 which have been skeptical of environmentalism were sponsored by conservative think tanks (Jacques et al., 2008). Moreover, Lewandowsky et al. (2013) indicate that rejection of science among conservatives may be suffused with a general tendency to endorse conspiracy theories. However, most of the studies about climate science acceptance have been conducted in an Anglo-American context and may thus overgeneralize the weight of some political and ideological factors (Bjornberg et al., 2017). For example, Hornsey et al. (2018) found that the positive relations between conspiratorial thinking, conservative ideologies and climate skepticism seems to be specific to the U.S. Nevertheless, as the line of research about collective narcissism and environmentalism is very new, future research should examine the extent to which the relation between collective narcissism and rejection of climate science might be explained by a third variable, namely, conservative ideology. Note that given that the left-right scale has conceptual and construct validity issues in many contexts (see Bauer et al., 2016), one should be very careful about the definition and measurement of this third variable. Also, conservatism can be operationalized as cultural or economic, and these 


\section{COLLECTIVE NARCISSISM AND CLIMATE CHANGE CONSPIRACY BELIEFS}

different types of conservatism are connected to different psychological characteristics, such as needs for security and certainty. There are also some country-level differences in these relations (Malka et al., 2014). One should also be careful about collinearity issues, that is, issues arising when independent variables are strongly correlated. Lastly, causality in the theoretical models should also be carefully defined, as controlling for a variable causally affected by the independent variable can not only result in spurious correlations, but also in the suppression of the effect under investigation (Rohrer, 2018).

Second, further research is also needed to overcome the cross-sectional limitations of our studies. An experimental design would be valuable to causally assert the path between collective narcissism and conspiracy beliefs. Also, it would be interesting to reverse the classic theorized causal path of collective narcissism leading to conspiracy beliefs (Cichocka et al., 2016). Indeed, it is quite plausible to think of collective narcissism as a consequence of conspiracy beliefs, with narcissistic self-categorization occurring due to suspicion of a threatening plot.

Future research might also be interested in replicating this finding with a cross-cultural perspective. Indeed, given the particularities of the U.S. population (Hornsey et al., 2018; Van der Linden et al., 2020), and the East European population (Malka et al, 214), a replication of our findings comparing different populations would be useful for the literature on climate science acceptance in general and in particular, its relationship to a conspiracy mentality. Furthermore, even though our samples reached the heuristic level for stabilized correlations (Schönbrodt \& Perugini, 2013), it would be useful to replicate our studies in a broader representative sample, as psychological science is in a post-replication crisis era (Anvari \& Lakens, 2018) and replication is needed for frequentist statistical inferences (Krueger, 2001).

Last, because no validated climate change conspiracy beliefs scale existed in the literature, we relied on a scale that we designed ourselves, as is the case in most research on 


\section{COLLECTIVE NARCISSISM AND CLIMATE CHANGE CONSPIRACY BELIEFS}

the topic. Given the importance of the topic of climate change, a psychometrically validated measurement of climate change conspiracy beliefs in different languages is needed. Such a measurement tool is even more necessary since these conspiracy beliefs have a number of particularities compared with other conspiracy theories (e.g., they do not blame industry and governments, but rather scientific groups).

\section{Conclusion}

Across three cross-sectional studies conducted in France, we found support for a mediation model in which climate change conspiracy beliefs mediate the relation between collective narcissism and rejection of climate science. This model held when controlling for age, gender, national identification and other forms of climate skepticism. Thus, our results suggest that collective narcissism is not only related to specific anti-conservation policies, but also more broadly to rejection of climate science.

Furthermore, we found that conspiracy mentality did not mediate this relation. Our research reinforces the observation that the results of previous studies carried out in the U.S might be specific to the American context (Hornsey, 2018). Lastly, we discussed the idea that whereas collective narcissistic identifiers are especially prone to hold conspiracy beliefs, this might be in a way that is context-relevant and not context-blind, as suggested by the monological belief system hypothesis.

\section{References}

Anvari, F., \& Lakens, D. (2018). The replicability crisis and public trust in psychological science. Comprehensive Results in Social Psychology, 3(3), 266-286. doi: $10.1080 / 23743603.2019 .1684822$

Bamberg, S. (2013). Changing environmentally harmful behaviors: A stage model of selfregulated behavioral change. Journal of Environmental Psychology, 34, 151-159. doi: 


\section{COLLECTIVE NARCISSISM AND CLIMATE CHANGE CONSPIRACY BELIEFS}

10.1016/j.jenvp.2013.01.002

Bertin, P., Nera, K., \& Delouvée, S. (2020). Conspiracy Beliefs, Rejection of Vaccination, and Support for hydroxychloroquine: A Conceptual Replication-Extension in the COVID-19 Pandemic Context. Frontiers in Psychology, 11, 2471. doi: 10.3389/fpsyg.2020.565128

Björnberg, K. E., Karlsson, M., Gilek, M., \& Hansson, S. O. (2017). Climate and environmental science denial: A review of the scientific literature published in 19902015. Journal of Cleaner Production, 167, 229-241. doi: 10.1016/j.jclepro.2017.08.066

Bliuc, A.-M., McGarty, C., Thomas, E. F., Lala, G., Berndsen, M., \& Misajon, R. (2015). Public division about climate change rooted in conflicting socio-political identities. Nature Climate Change, 5(3), 226. doi: 10.1038/nclimate2507

Bruder, M., Haffke, P., Neave, N., Nouripanah, N., \& Imhoff, R. (2013). Measuring individual differences in generic beliefs in conspiracy theories across cultures: Conspiracy Mentality Questionnaire. Frontiers in Psychology, 4, 225. doi: 10.3389/fpsyg.2013.00225

Cichocka, A. (2016). Understanding defensive and secure in-group positivity: The role of collective narcissism. European Review of Social Psychology, 27(1), 283-317. doi: $10.1080 / 10463283.2016 .1252530$

Cichocka, A., Golec de Zavala, A., Marchlewska, M., \& Olechowski, M. (2015). Grandiose 


\section{COLLECTIVE NARCISSISM AND CLIMATE CHANGE CONSPIRACY BELIEFS}

delusions: Collective narcissism, secure in-group identification, and belief in conspiracies. doi: 10.4324/9781315746838-9

Cichocka, A., Marchlewska, M., Golec de Zavala, A., \& Olechowski, M. (2016). 'They will not control us': Ingroup positivity and belief in intergroup conspiracies. British Journal of Psychology, 107(3), 556-576. doi: 10.1111/bjop.12158

Cislak, A., Wojcik, A. D., \& Cichocka, A. (2018). Cutting the forest down to save your face: Narcissistic national identification predicts support for anti-conservation policies. Journal of Environmental Psychology, 59, 65-73. doi: 10.1016/j.jenvp.2018.08.009

Cologna, V., \& Siegrist, M. (2020). The role of trust for climate change mitigation and adaptation behaviour: A meta-analysis. Journal of Environmental Psychology, 101428. doi: 10.1016/j.jenvp.2020.101428

Conspiracy Watch. (2019, January). Enquête sur le complotisme - Vague 2 [Conspiracy Investigation - Phase 2]. Retrieved from: https://jeanjaures.org/sites/default/files/redac/commun/productions/2019/0220/rapport_complot.p df.

Cook, J., Nuccitelli, D., Green, S. A., Richardson, M., Winkler, B., Painting, R., Way, R., Jacobs, P., \& Skuce, A. (2013). Quantifying the consensus on anthropogenic global warming in the scientific literature. Environmental Research Letters, 8(2), 024024. doi: $10.1088 / 1748-9326 / 8 / 2 / 024024$

Cook, J., Oreskes, N., Doran, P. T., Anderegg, W. R. L., Verheggen, B., Maibach, E. W., 


\section{COLLECTIVE NARCISSISM AND CLIMATE CHANGE CONSPIRACY BELIEFS}

Carlton, J. S., Lewandowsky, S., Skuce, A. G., Green, S. A., Nuccitelli, D., Jacobs, P., Richardson, M., Winkler, B., Painting, R., \& Rice, K. (2016). Consensus on consensus: A synthesis of consensus estimates on human-caused global warming. Environmental Research Letters, 11(4), 048002. doi: 10.1088/1748-9326/11/4/048002

Diethelm, P., \& McKee, M. (2009). Denialism: What is it and how should scientists respond? European Journal of Public Health, 19(1), 2-4. doi: 10.1093/eurpub/ckn139

Douglas, K. M., \& Sutton, R. M. (2015). Climate change: Why the conspiracy theories are dangerous. Bulletin of the Atomic Scientists, 71(2), 98-106. doi:

$10.1177 / 0096340215571908$

Douglas, K. M., \& Sutton, R. M. (2018). Why conspiracy theories matter: A social psychological analysis. European Review of Social Psychology, 29(1), 256-298. doi: $10.1080 / 10463283.2018 .1537428$

Douglas, K. M., Uscinski, J. E., Sutton, R. M., Cichocka, A., Nefes, T., Ang, C. S., \& Deravi, F. (2019). Understanding conspiracy theories. Political Psychology, 40, 3-35. doi: 10.1111/pops. 12568

Dunn, T. J., Baguley, T., \& Brunsden, V. (2014). From alpha to omega: A practical solution to the pervasive problem of internal consistency estimation. British Journal of Psychology, 105(3), 399-412. doi: 10.1111/bjop.12046

Ecklund, E. H., Scheitle, C. P., Peifer, J., \& Bolger, D. (2017). Examining Links Between Religion, Evolution Views, and Climate Change Skepticism. Environment and 


\section{COLLECTIVE NARCISSISM AND CLIMATE CHANGE CONSPIRACY BELIEFS}

Behavior, 49(9), 985-1006. doi: 10.1177/0013916516674246

Einstein, K. L., \& Glick, D. M. (2013). Scandals, conspiracies and the vicious cycle of cynicism. Annual Meeting of the American Political Science Association. doi: $10.1177 / 0013916516674246$

Feygina, I. (2012). The challenge of system justification for acknowledging and responding to environmental dilemmas and climate change [PhD Thesis]. New York University. doi: 10.1037/e586882013-001

Frantz, C., Mayer, F. S., Norton, C., \& Rock, M. (2005). There is no "I” in nature: The influence of self-awareness on connectedness to nature. Journal of Environmental Psychology, 25(4), 427-436. doi: 10.1016/j.jenvp.2005.10.002

Fritsche, I., Barth, M., Jugert, P., Masson, T., \& Reese, G. (2018). A social identity model of pro-environmental action (SIMPEA). Psychological Review, 125(2), 245. doi: $10.1037 /$ rev0000090

Fritsche, I., Cohrs, J. C., Kessler, T., \& Bauer, J. (2012). Global warming is breeding social conflict: The subtle impact of climate change threat on authoritarian tendencies. Journal of Environmental Psychology, 32(1), 1-10. doi: 10.1016/j.jenvp.2011.10.002

Fritsche, I., Jonas, E., \& Kessler, T. (2011). Collective Reactions to Threat: Implications for Intergroup Conflict and for Solving Societal Crises. Social Issues and Policy Review, 5(1), 101-136. doi: 10.1111/j.1751-2409.2011.01027.x

Galliford, N., \& Furnham, A. (2017). Individual difference factors and beliefs in medical and 


\section{COLLECTIVE NARCISSISM AND CLIMATE CHANGE CONSPIRACY BELIEFS}

political conspiracy theories. Scandinavian Journal of Psychology, 58(5), 422-428. doi: $10.1111 /$ sjop. 12382

Gallucci, M. (2020). jamovi Advanced Mediation Models Package (version 1.0.4). Retrieved from https://jamovi-amm.github.io/

Goertzel, T. (2010). Conspiracy theories in science: Conspiracy theories that target specific research can have serious consequences for public health and environmental policies. EMBO Reports, 11(7), 493-499. doi: 10.1038/embor.2010.84

Goldsby, M., \& Koolage, W. J. (2015). Climate modeling: Comments on coincidence, conspiracy, and climate change denial. Environmental Philosophy, 12(2), 221-252. doi: 10.5840/envirophil2015102625

Golec de Zavala, A. (2020). Why is populism so robustly associated with conspiratorial thinking? Collective Narcissism and the Meaning Maintenance Model. doi: 10.1007/978-3-030-38270-4_12

Golec de Zavala, A., Cichocka, A., Eidelson, R., \& Jayawickreme, N. (2009). Collective narcissism and its social consequences. Journal of Personality and Social Psychology, 97(6), 1074. doi: 10.1037/a0016904

Golec de Zavala, A., Cichocka, A., \& Iskra-Golec, I. (2013). Collective narcissism moderates the effect of in-group image threat on intergroup hostility. Journal of Personality and Social Psychology, 104(6), 1019. doi: 10.1037/a0032215

Golec de Zavala, A., Dyduch-Hazar, K., \& Lantos, D. (2019). Collective Narcissism: Political 


\section{COLLECTIVE NARCISSISM AND CLIMATE CHANGE CONSPIRACY BELIEFS}

Consequences of Investing Self-Worth in the Ingroup's Image. Political Psychology, 40, 37-74. doi: 10.1111/pops.12569

Golec de Zavala, A., \& Federico, C. M. (2018). Collective narcissism and the growth of conspiracy thinking over the course of the 2016 United States presidential election: A longitudinal analysis. European Journal of Social Psychology, 48(7), 1011-1018. doi: 10.1002/ejsp.2496

Golec de Zavala, A., \& Lantos, D. (2020). Collective narcissism and its social consequences: The Bad and the Ugly. Current Directions in Psychological Science, 29(3), 273-278. doi: $10.1177 / 0963721420917703$

Golec de Zavala, A., Peker, M., Guerra, R., \& Baran, T. (2016). Collective narcissism predicts hypersensitivity to in-group insult and direct and indirect retaliatory intergroup hostility. European Journal of Personality, 30(6), 532-551. doi: 10.1002/per.2067

Haltinner, K., \& Sarathchandra, D. (2018). Climate change skepticism as a psychological coping strategy. Sociology Compass, 12(6), e12586. doi: 10.1111/soc4.12586

Hamer, K., Penczek, M., \& Bilewicz, M. (2018). Between universalistic and defensive forms of group attachment. The indirect effects of national identification on intergroup forgiveness. Personality and Individual Differences, 131, 15-20. doi: 10.1016/j.paid.2018.03.052

Hamer, K., Penczek, M., McFarland, S., Wlodarczyk, A., ILużniak-Piecha, M., Golińska, A., 


\section{COLLECTIVE NARCISSISM AND CLIMATE CHANGE CONSPIRACY BELIEFS}

Cadena, L. M., Ibarra, M., Bertin, P., \& Delouvée, S. (2020). Identification with all humanity - A test of the factorial structure and measurement invariance of the scale in

five countries. International Journal of Psychology. doi: 10.1002/ijop.12678

Hansson, S. O. (2017). Science denial as a form of pseudoscience. Studies in History and Philosophy of Science Part A, 63, 39-47. doi: 10.1016/j.shpsa.2017.05.002

Hornsey, M. J., Harris, E. A., \& Fielding, K. S. (2018). Relationships among conspiratorial beliefs, conservatism and climate scepticism across nations. Nature Climate Change, 8(7), 614-620. doi: 10.1038/s41558-018-0157-2

Hotez, P. J. (2020a). Combating antiscience: Are we preparing for the 2020s? PLoS Biology, 18(3). doi: 10.1371/journal.pbio.3000683

Hotez, P. J. (2020b). Anti-science extremism in America: Escalating and globalizing. Microbes and Infection. doi: 10.1016/j.micinf.2020.09.005

Jacques, P. J., Dunlap, R. E., \& Freeman, M. (2008). The organisation of denial: Conservative think tanks and environmental scepticism. Environmental Politics, 17(3), 349-385. doi: 10.1080/09644010802055576

Jolley, D., \& Douglas, K. M. (2014a). The social consequences of conspiracism: Exposure to conspiracy theories decreases intentions to engage in politics and to reduce one's carbon footprint. British Journal of Psychology, 105(1), 35-56. doi: 10.1111/bjop. 12018

Jolley, D., \& Douglas, K. M. (2014b). The Effects of Anti-Vaccine Conspiracy Theories on 


\section{COLLECTIVE NARCISSISM AND CLIMATE CHANGE CONSPIRACY BELIEFS}

Vaccination Intentions. PLoS ONE, 9(2). doi: 10.1371/journal.pone.0089177

Jolley, D., Meleady, R., \& Douglas, K. M. (2019). Exposure to intergroup conspiracy theories promotes prejudice which spreads across groups. British Journal of Psychology. doi: 10.1111/bjop.12385

Jolley, D., \& Paterson, J. L. (2020). Pylons ablaze: Examining the role of 5G COVID-19 conspiracy beliefs and support for violence. British Journal of Social Psychology. doi: 10.1111/bjso.12394

Jonas, E., McGregor, I., Klackl, J., Agroskin, D., Fritsche, I., Holbrook, C., Nash, K., Proulx, T., \& Quirin, M. (2014). Threat and Defense. In Advances in Experimental Social Psychology (Vol. 49, pp. 219-286). Elsevier. doi: 10.1016/B978-0-12-800052$6.00004-4$

Krueger, J. (2001). Null hypothesis significance testing: On the survival of a flawed method. American Psychologist, 56(1), 16. doi: 10.1037/0003-066X.56.1.16

Lantian, A., Muller, D., Nurra, C., \& Douglas, K. M. (2016). Measuring belief in conspiracy theories: Validation of a French and English single-item scale. International Review of Social Psychology, 29(1), 1-14. doi: 10.5334/irsp.8

Larkin, B., \& Fink, J. S. (2019). Toward a better understanding of fan aggression and dysfunction: The moderating role of collective narcissism. Journal of Sport Management, 33(2), 69-78. doi:10.1123/jsm.2018-0012

Lewandowsky, S., Gignac, G. E., \& Oberauer, K. (2013). The Role of Conspiracist Ideation 


\section{COLLECTIVE NARCISSISM AND CLIMATE CHANGE CONSPIRACY BELIEFS}

and Worldviews in Predicting Rejection of Science. PLoS ONE, 8(10), e75637. doi: 10.1371/journal.pone.0075637

Lewandowsky, S., \& Oberauer, K. (2016). Motivated rejection of science. Current Directions in Psychological Science, 25(4), 217-222. doi: 10.1177/0963721416654436

Lewandowsky, S., Oberauer, K., \& Gignac, G. E. (2013). NASA Faked the Moon Landing--Therefore, (Climate) Science Is a Hoax: An Anatomy of the Motivated Rejection of Science. 13. doi: 10.1177/0956797612457686

Malka, A., Soto, C. J., Inzlicht, M., \& Lelkes, Y. (2014). Do needs for security and certainty predict cultural and economic conservatism? A cross-national analysis. Journal of Personality and Social Psychology, 106(6), 1031. doi: 10.1037/a0036170

Marchlewska, M., Cichocka, A., Łozowski, F., Górska, P., \& Winiewski, M. (2019). In search of an imaginary enemy: Catholic collective narcissism and the endorsement of gender conspiracy beliefs. The Journal of Social Psychology, 159(6), 766-779. doi: $10.1080 / 00224545.2019 .1586637$

Marchlewska, M., Cichocka, A., Panayiotou, O., Castellanos, K., \& Batayneh, J. (2018). Populism as identity politics: Perceived in-group disadvantage, collective narcissism, and support for populism. Social Psychological and Personality Science, 9(2), 151162. doi:10.1177/1948550617732393

Marinthe, G., Brown, G., Delouvée, S., \& Jolley, D. (2020). Looking out for myself: Exploring the relationship between conspiracy mentality, perceived personal risk and 


\section{COLLECTIVE NARCISSISM AND CLIMATE CHANGE CONSPIRACY BELIEFS}

COVID-19 prevention measures. doi: 10.31234/osf.io/cm9st

McFarland, S., Hackett, J., Hamer, K., Katzarska-Miller, I., Malsch, A., Reese, G., \& Reysen,

S. (2019). Global Human Identification and Citizenship: A Review of Psychological

Studies. Political Psychology, 40(S1), 141-171. doi: 10.1111/pops.12572

McFarland, S., Webb, M., \& Brown, D. (2012). All humanity is my ingroup: A measure and studies of identification with all humanity. Journal of Personality and Social Psychology, 103(5), 830. doi: 10.1037/a0028724

Moscovici, S. (1987). The conspiracy mentality. In Changing conceptions of conspiracy (pp. 151-169). Springer. doi: 10.1007/978-1-4612-4618-3_9

Naderi, I., \& Strutton, D. (2014). Can normal narcissism be managed to promote green product purchases? Investigating a counterintuitive proposition. Journal of Applied Social Psychology, 44(5), 375-391. doi: 10.1111/jasp.12230

Poortinga, W., Spence, A., Whitmarsh, L., Capstick, S., \& Pidgeon, N. F. (2011). Uncertain climate: An investigation into public scepticism about anthropogenic climate change. Global Environmental Change, 21(3), 1015-1024. doi: 10.1016/j.gloenvcha.2011.03.001

Rohrer, J. M. (2018). Thinking clearly about correlations and causation: Graphical causal models for observational data. Advances in Methods and Practices in Psychological Science, 1(1), 27-42. doi: 10.1177/2515245917745629

Rutjens, B. T., Sutton, R. M., \& van der Lee, R. (2018). Not all skepticism is equal: Exploring 


\section{COLLECTIVE NARCISSISM AND CLIMATE CHANGE CONSPIRACY BELIEFS}

the ideological antecedents of science acceptance and rejection. Personality and Social Psychology Bulletin, 44(3), 384-405. doi: 10.1177/0146167217741314

Schönbrodt, F. D., \& Perugini, M. (2013). At what sample size do correlations stabilize?

Journal of Research in Personality, 47(5), 609-612. doi: 10.1016/j.jrp.2013.05.009

Sternisko, A., Cichocka, A., \& Van Bavel, J. J. (2020). The dark side of social movements:

Social identity, non-conformity, and the lure of conspiracy theories. Current opinion in psychology, 35, 1-6.. doi: 10.1016/j.copsyc.2020.02.007

Stoll-Kleemann, S., \& Schmidt, U. J. (2017). Reducing meat consumption in developed and transition countries to counter climate change and biodiversity loss: A review of influence factors. Regional Environmental Change, 17(5), 1261-1277. doi: $10.1007 / \mathrm{s} 10113-016-1057-5$

Swami, V., Barron, D., Weis, L., Voracek, M., Stieger, S., \& Furnham, A. (2017). An examination of the factorial and convergent validity of four measures of conspiracist ideation, with recommendations for researchers. PloS One, 12(2). doi: 10.1371/journal.pone.0172617

Tranter, B., \& Booth, K. (2015). Scepticism in a changing climate: A cross-national study. Global Environmental Change, 33, 154-164. doi: 10.1016/j.gloenvcha.2015.05.003

Uhl, I., Jonas, E., \& Klackl, J. (2016). When climate change information causes undesirable side effects: The influence of environmental self-identity and biospheric values on threat responses/Cuando la información sobre el cambio climático tiene efectos 


\section{COLLECTIVE NARCISSISM AND CLIMATE CHANGE CONSPIRACY BELIEFS}

indeseados: la influencia de la identidad ambiental y de los valores biosféricos en la respuesta ante una amenaza. Psyecology, 7(3), 307-334. doi:

$10.1080 / 21711976.2016 .1242228$

Uhl, I., Klackl, J., Hansen, N., \& Jonas, E. (2018). Undesirable effects of threatening climate change information: A cross-cultural study. Group Processes \& Intergroup Relations, 21(3), 513-529. doi: 10.1177/1368430217735577

Uscinski, J. E., Douglas, K., \& Lewandowsky, S. (2017). Climate Change Conspiracy

Theories. In J. E. Uscinski, K. Douglas, \& S. Lewandowsky, Oxford Research Encyclopedia of Climate Science. Oxford University Press. doi: 10.1093/acrefore/9780190228620.013.328

van der Linden, S. L., Leiserowitz, A. A., Feinberg, G. D., \& Maibach, E. W. (2015). The Scientific Consensus on Climate Change as a Gateway Belief: Experimental Evidence. PLOS ONE, 10(2), e0118489. doi: 10.1371/journal.pone.0118489

van der Linden, S., Panagopoulos, C., Azevedo, F., \& Jost, J. T. (2020). The paranoid style in American politics revisited: an ideological asymmetry in conspiratorial thinking. Political Psychology. doi: 10.1111/pops.12681

van der Linden, S., \& Rosenthal, S. A. (2016). Measuring narcissism with a single question? A replication and extension of the Single-Item Narcissism Scale (SINS). Personality and Individual Differences, 90, 238-241. doi: 10.1016/j.paid.2015.10.050

Washburn, A. N., \& Skitka, L. J. (2018). Science Denial Across the Political Divide: Liberals 


\section{COLLECTIVE NARCISSISM AND CLIMATE CHANGE CONSPIRACY BELIEFS}

and Conservatives Are Similarly Motivated to Deny Attitude-Inconsistent Science.

Social Psychological and Personality Science, 9(8), 972-980. doi:

$10.1177 / 1948550617731500$

\section{Appendix A}

\section{Collective Narcissism Scale, French version}

1. J'aimerais que les autres groupes reconnaissent plus rapidement l'autorité de la nation française

2. La nation française mérite un traitement de faveur

3. Je ne serai satisfait que lorsque la nation française obtiendra la reconnaissance qu'il mérite

4. J'insiste pour que la nation française reçoive le traitement qui lui est dû

5. Cela me met très en colère lorsque d'autres personnes critiquent la nation française

6. Je ne suis pas contrarié quand les réussites de la nation française passent inaperçues $(\mathrm{R})$

7. Le monde serait bien meilleur si la nation française y jouait un rôle majeur

8. Peu de gens semble pleinement comprendre l'importance de la nation française

9. La véritable valeur de la nation française est souvent sous-estimée

Note. Translated from Golec de Zavala and colleagues (2009)

$\mathrm{R}=$ reversed item, short form (pilot study and Study 1): items 2, 3, 5, 6, 8 


\section{Appendix B}

\section{Climate change conspiracy beliefs Scale}

\section{French version}

1. L'affirmation que le changement climatique est causé par les activités humaines est une supercherie perpétrée par des scientifiques corrompus qui espèrent dépenser davantage l'argent du contribuable dans la recherche sur le climat (pilot study, Study 1, Study 2)

2. Certains scientifiques falsifient leurs résultats, affirmant que le changement climatique est dû aux êtres humains, afin de gagner en pouvoir et en influence (pilot study, Study 2)

3. Pour imposer leurs réformes politiques néo-libérales, les gouvernements occidentaux développent l'idée selon laquelle le changement climatique serait dû aux activités humaines (pilot study, Study 1, Study 2)

4. L'état, de mèche avec de grands groupes privés, cherche à promouvoir l'énergie nucléaire en répandant l'idée que l'être humain émet trop de carbone et que cela cause le changement climatique (pilot study, Study 2)

5. Certaines compagnies financent de fausses recherches alarmistes sur le changement climatique afin de sécuriser leurs investissements dans les énergies renouvelables (pilot Study)

6. Pour augmenter leur profit, certaines multinationales s'entendent pour financer des organisations qui accusent l'être humain d'être à l'origine du changement climatique (Study 1) 


\section{COLLECTIVE NARCISSISM AND CLIMATE CHANGE CONSPIRACY BELIEFS}

7. Certaines compagnies ayant investi de grandes sommes d'argent dans les énergies renouvelables financent de fausses recherches alarmistes sur le changement climatique afin de sécuriser leurs investissements (Study 2)

\section{English version}

1. The claim that the climate is changing due to emissions from fossil fuels is a hoax perpetrated by corrupt scientists who wish to spend more taxpayer money on climate research (pilot study, Study 1, Study 2)

2. Some scientists falsify their results, concluding that climate change is due to humans, in order to gain power and influence (pilot study, Study 2)

3. In order to impose their neo-liberal political reforms, Western governments are developing the idea that climate change is caused by human activities (pilot study, Study 1, Study 2)

4. The government, in cahoots with large private groups, seeks to promote nuclear energy by spreading the idea that human beings emit too much carbon and that this causes climate change (pilot study, Study 2)

5. Some companies are funding false climate change alarmist research to secure their investments in renewable energy (pilot study)

6. In order to increase their profits, some multinationals agree to finance organizations that accuse human beings of being the cause of climate change (Study 1)

7. Some companies having invested large sums of money in renewable energies are financing worrisome research into climate change in order to secure their investment (Study 2) 


\section{Appendix C}

\section{Acceptance of Climate Science, French Version (Study 1)}

1. Je crois que le climat a toujours changé et ce que nous observons actuellement est simplement une fluctuation naturelle $(\mathrm{R})$

2. Je crois que la combustion des énergies fossiles lors des 50 dernières années a causé de graves dommages au climat mondial

3. Les émissions de $\mathrm{CO} 2$ humaines causent le changement climatique

4. Les humains sont trop insignifiants pour avoir un impact significatif sur la température mondiale $(\mathrm{R})$

Note. $\mathrm{R}=$ reversed item, item 1 is from Lewandowsky, Gignac, and Oberauer (2013)

\section{Acceptance of climate science, French Version (Study 2)}

1. Je crois que la combustion des énergies fossiles augmente la température atmosphérique de manière notable.

2. Je crois que la combustion des énergies fossiles dans les proportions observées durant les 50 dernières années a augmenté la température atmosphérique de manière palpable.

3. Je crois que la combustion des énergies fossiles dans les proportions observées durant les 50 dernières années va causer d'importants changements négatifs au climat de la planète, à moins qu'un changement substantiel vers les énergies nonémettrices de $\mathrm{CO} 2$ ait lieu.

4. Je crois que la combustion des énergies fossiles dans les proportions observées durant les 50 dernières années a causé de sérieux dégâts au le climat de la planète. 
COLLECTIVE NARCISSISM AND CLIMATE CHANGE CONSPIRACY BELIEFS

Note. Translated from Lewandowsky, Oberauer, and Gignac (2013)

\section{Appendix D}

\section{Climate skepticism, French Version}

\section{Trend skepticism}

Je ne suis pas certain que le changement climatique se produise réellement

\section{Attribution skepticism}

La plupart des scientifiques sont d'accord pour dire que les êtres humains causent le changement climatique

\section{Impact skepticism}

1. La gravité du changement climatique est exagérée

2. Les effets qui seront causés par le changement climatique sont incertains

Note. Translated from Poortinga et al. (2011) 


\section{Figures}

\section{Figure 1}

Mediation Model (Studies 1-2)

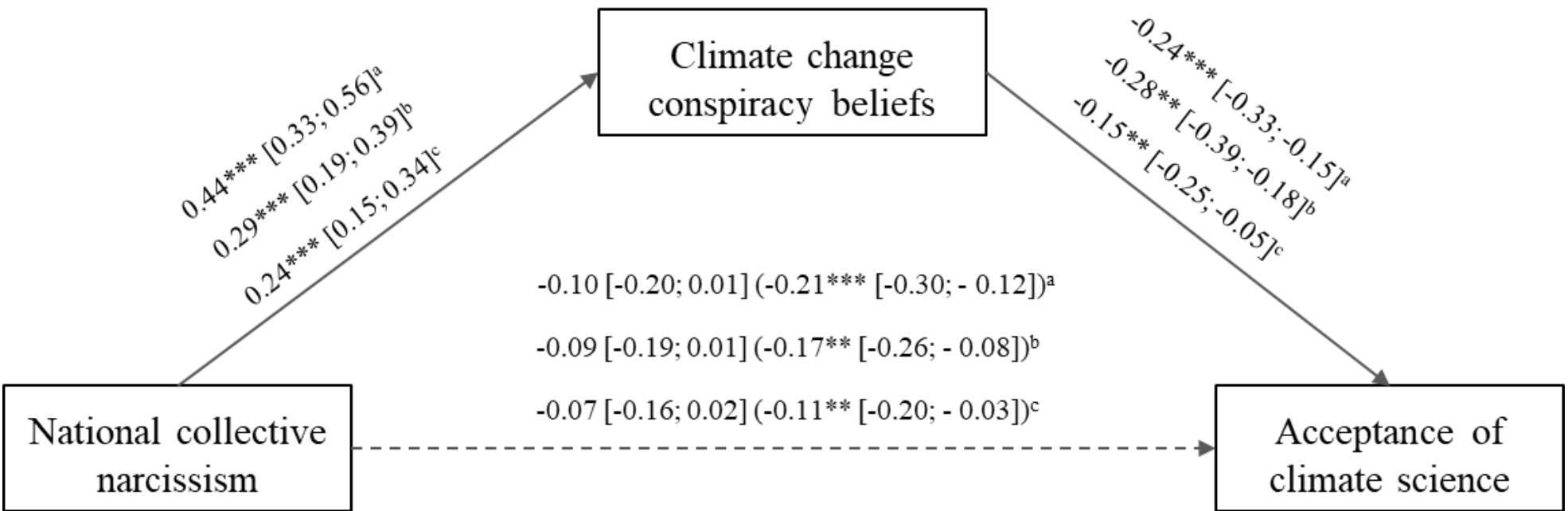

Note. Study 1, ${ }^{\mathrm{b}}$ Study $2,{ }^{\mathrm{c}}$ Study 2 controlling for other forms of climate scepticism.

Coefficients are unstandardized. For each path, we controlled for age, gender and national identification.

$* * p<.01 * * * p<.001$.

\section{Figure 2}

Alternative Mediation Model (Study 2)

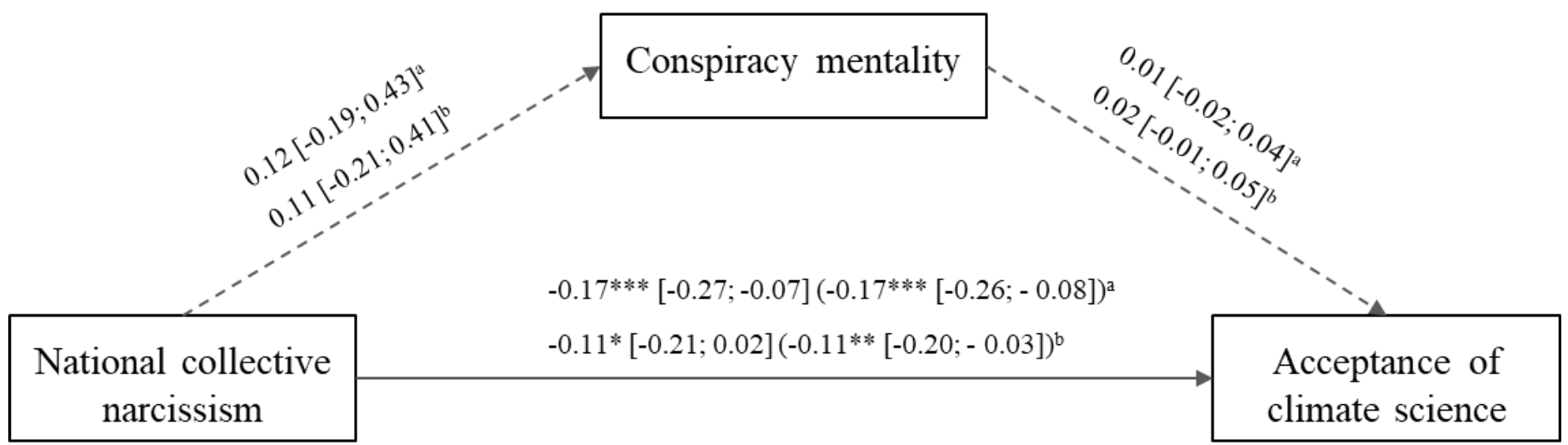

Note. ${ }^{\mathrm{a}}$ Study 2 , ${ }^{\mathrm{b}}$ Study 2 controlling for other forms of climate scepticism. Coefficients are unstandardized. For each path, we controlled for age, gender and national identification. $* p<.05 * * p<.01 * * * p<.001$. 


\section{Tables}

\section{Table 1}

Correlations, Means, Standard Deviations, and Internal Reliability Coefficients for Measured Variables (Pilot Study)

\begin{tabular}{|c|c|c|c|c|c|c|c|}
\hline & Mean & $S D$ & $\alpha$ & $\omega$ & 1. & 2. & 3. \\
\hline 1. National collective narcissism & 1.66 & 0.75 & .83 & .83 & - & & \\
\hline 2. National identification & 3.44 & 0.76 & .70 & .70 & -.01 & - & \\
\hline 3. Conspiracy beliefs about climate change & 2.17 & 0.87 & .85 & .86 & $.35 * * *$ & .01 & - \\
\hline
\end{tabular}

Note. $N=409$. All variables were measured using a 5-point Likert scale.

$* * * p<.001$.

\section{Table 2}

Hierarchical Regressions on Climate Change Conspiracy Beliefs (Pilot Study)

\begin{tabular}{|c|c|c|c|c|c|}
\hline \multirow{3}{*}{ Independent variable } & \multicolumn{5}{|c|}{ Dependent variable } \\
\hline & \multicolumn{5}{|c|}{ Climate change conspiracy beliefs } \\
\hline & $B$ & $95 \% C I$ & $t$ & $p$ & Total $R^{2}$ \\
\hline Step 1 & & & & & .032 \\
\hline Gender & 0.14 & {$[-0.03 ; 0.30]$} & 1.64 & .101 & \\
\hline Age & 0.01 & {$[0.01 ; 0.2]$} & 3.25 & .001 & \\
\hline National identity & 0.01 & {$[-0.08 ; 0.11]$} & 0.22 & .828 & \\
\hline Step 2 & & & & & .14 \\
\hline Gender & 0.14 & {$[-0.08 ; 0.30]$} & 1.85 & .07 & \\
\hline Age & 0.08 & {$[-0.01 ; 0.01]$} & 1.77 & .07 & \\
\hline National identification & 0.01 & {$[-0.08 ; 0.11]$} & 0.32 & .75 & \\
\hline National collective narcissism & 0.30 & {$[0.21 ; 0.38]$} & 7.08 & $<.001$ & \\
\hline
\end{tabular}


Note. $N=409$.

\section{Table 3}

Correlations, Means, Standard Deviations, and Internal Reliability Coefficients for Measured Variables (Study 1)

$\begin{array}{ccccccc}\text { Mean } & S D & \alpha & \omega & 1 . & 2 . & 3 . \\ 2.28 & 0.76 & .81 & .82 & - & & \\ 3.39 & 0.70 & .66 & .67 & .17 * * & - & \\ 2.05 & 0.83 & .68 & .69 & .37 * * * & -.05 & - \\ 3.95 & 0.62 & .55 & .58 & -.22^{* * *} & .08 & -.38^{* * *}\end{array}$

Note. $N=295$. All variables were measured using a 5-point Likert scale.

$* * p<.01 * * * p<.001$.

\section{Table 4}

Linear Regression on Acceptance of Climate Science (Study 1)

Dependent variable

Independent variable

Acceptance of climate science

\begin{tabular}{lcccc}
\hline & $B$ & $95 \% C I$ & $t$ & $p$ \\
\hline Gender & -0.19 & {$[-0.38 ;-0.01]$} & -2.05 & .04 \\
Age & -0.01 & {$[-0.03 ; 0.01]$} & -1.23 & .22 \\
National identification & 0.13 & {$[0.03 ; 0.23]$} & 2.54 & 0.012 \\
National collective narcissism & -0.21 & {$[-0.30 ;-0.11]$} & -4.48 & $<.001$ \\
\hline
\end{tabular}

Note. $N=409$ 
COLLECTIVE NARCISSISM AND CLIMATE CHANGE CONSPIRACY BELIEFS

\section{Table 5}

Correlations, Means, and Standard Deviations, Internal Reliability Coefficients and Pearson's correlation coefficients (Study 2)

\begin{tabular}{|c|c|c|c|c|c|c|c|c|c|c|c|}
\hline & Mean & $S D$ & $\alpha$ & $\omega$ & 1. & 2. & 3. & 4. & 5. & 6. & 7. \\
\hline 1. National collective narcissism & 2.03 & 0.82 & .85 & .87 & - & & & & & & \\
\hline 2. National identification & 2.89 & 0.64 & .84 & .84 & $.36 * * *$ & - & & & & & \\
\hline 3. Conspiracy beliefs about climate change & 1.73 & 0.71 & .82 & .83 & $.33 * * *$ & $.11 *$ & & & & & \\
\hline 4. Acceptance of climate science & 4.24 & 0.70 & .88 & .88 & $-.20 * * *$ & -.04 & $-.33 * * *$ & - & & & \\
\hline 5. Trend skepticism & 1.56. & 0.89 & - & - & $.13^{*}$ & -.01 & $.27 * * *$ & $-.28 * * *$ & - & & \\
\hline 6. Attribution skepticism & 1.76 & 0.79 & - & - & $.12^{*}$ & $.10+$ & $.25^{* * *}$ & $-.32 * * *$ & $.13^{* *}$ & - & \\
\hline 7. Impact skepticism & 2.21 & 0.77 & - & - & $.09+$ & -.03 & $.22 * * *$ & $-.37 * * *$ & $.33 * * *$ & $.27 * * *$ & - \\
\hline 8. CMQ & 6.56 & 2.10 & .88 & .89 & .06 & .05 & $.21 * * *$ & .01 & .01 & .06 & .04 \\
\hline
\end{tabular}

Note. $N=375$. All variables were measured using a 5-points Likert scale, except for national collective narcissism (6 points) and CMQ (11 points).

$+p<.10 * p<.05 * * p<.01 * * * p<.001$. 
Table 6

Hierarchical Regressions on Acceptance of Climate Science (Study 2)

\section{Dependent variable}

Independent variable Acceptance of climate science

\begin{tabular}{lcccc}
\hline & $B$ & $95 \% C I$ & $t$ & $p$ \\
\hline Gender & -0.15 & {$[-0.31 ; 0.01]$} & -1.92 & .06 \\
Age & 0.01 & {$[-0.01 ; 0.01]$} & 1.85 & .07 \\
National identification & 0.04 & {$[-0.08 ; 0.16]$} & 0.69 & .49 \\
National collective narcissism & -0.17 & {$[-0.26 ;-0.08]$} & 3.61 & $<.001$ \\
\hline
\end{tabular}

Note. $N=409$. 